\title{
Mountain regions in the legal space of Russia
}

\author{
Alexey Gunya ${ }^{1, *}$, Yuri Badenkov ${ }^{1}$, and Shahmardan Muduev ${ }^{2}$ \\ ${ }^{1}$ Institute of Geography, Russian Academy of Sciences, 29, Staromonetny per., Moscow, 119017, Russia \\ ${ }^{2}$ Dagestan state University of national economy, st. Ataeva, 5, Makhachkala, Rep. Dagestan, 367008, Russia
}

\begin{abstract}
The allocation of the mountainous regions of Russia as a subject of legal regulation is a relatively new trend in Russian lawmaking, which began in the 1990s. The initiation of the process of developing mountain laws was influenced by the international experience of European countries that have mountain areas in their composition. An important event at the end of 2020 is the adoption by the CIS Interparliamentary Assembly of the Model Law "On the Protection and Development of Mountain Areas". The purpose of the article is to analyze modern initiatives in the field of legal support for the sustainable development of the mountain regions of Russia. The results are based on an analysis of documents adopted in the field of mountain legislation, as well as on interviews with experts and expeditionary work. The program for the development of the mountainous territories of Dagestan, initiated on the basis of the implementation of the regional law on mountainous territories, became a certain "litmus" test that revealed the problems of modernization and ensuring sustainable development in the mountains. These include, first of all, distrust of the government's initiatives, unsettled land relations, fear of getting into credit dependence, the complexity of bureaucratic procedures, etc.
\end{abstract}

\section{Introduction}

Russia has huge regional differences in natural conditions and living environment. Accounting for natural differences is presented in such state governance instruments as strategic planning and regional development. In the context of the state regional policy concerning the consideration of the spatial characteristics of Russia, its natural contrasts, the greatest attention is paid to the differences caused by the country's position in the extreme natural and climatic conditions of the North. Much less attention is paid to the mountain specifics of Russia. Meanwhile, mountains occupy more than $50 \%$ of the country's territory and are characterized by no less difficult conditions for living and developing. The recognition of the importance of mountain specificity in state policy is unequally expressed in the improvement of legal mechanisms at the regional, federal and international levels.

Since the mid-1990s, the problems of sustainable development of the mountainous regions of Russia have been included in the national development agenda thanks to the inclusion of mountain Chapter 13 "Managing Fragile Ecosystems: Sustainable Mountain Development"a in the Global Agenda XXI (1992) at the UN Summit in Rio (1992) and thanks to activity of scientists (Mountain group MAB-6 / Institute of Geography RAS, first of all) and two republics - Altai and North Ossetia-Alania. The latter were at that time

${ }^{a}$ http://www.fao.org/forestry/11704-

08f16e5634e988978a1d0b2cf2cf922e0.pdf the locomotives of the mining movement in the Russian Federation.

In the same period, the initiative for the development and adoption of the Federal Law on the Socio-Economic Development of the Mountain Regions of Russia appeared. In 1998, the Republic of North Ossetia-Alania adopted the first mountain law in Russia (and the CIS countries!). So the legal framework for the development of mountainous regions in Russia has its own almost 30year history and specificity [1].

An important event at the end of 2020 is the adoption by the CIS Interparliamentary Assembly of the Model Law "On the Protection and Development of Mountain Areas"b. Intensive discussions that accompanied the development of all 10 chapters and 39 articles of the law involved scientists and the public of universities and academic institutes of the Russian Academy of Sciences, as well as scientists and experts from the CIS countries. The preamble to the Model Law reads: "Mountains and hills occupy a significant part of the vast space of the Commonwealth of Independent States. The mountainous regions of the CIS member states are located in different physical and geographical zones and are characterized by exceptional natural, ethnocultural and historical diversity. The mountains are the custodians and suppliers of natural resources on which life depends on the surrounding lowlands and remote urbanized and industrial centers. In this aspect, mountains play a prominent role in national strategies and programs for

\footnotetext{
${ }^{\mathrm{b}} \mathrm{https}$ //iacis.ru/baza_dokumentov/modelnie_zakonodatelnie_a
} kti_i_rekomendatcii_mpa_sng/modelnie_kodeksi_i_zakoni

* Corresponding author: a.n.gunya@igras.ru 
socio-economic development. "The model laws adopted by the Interparliamentary Assembly CIS are of a recommendatory nature. However, they often lay the foundations for improving national legislation. The adoption of the law will allow the mountainous participating countries to develop their own strategies (and, possibly, their own laws on mountains!), which will take into account the vulnerability of mountain ecosystems to anthropogenic and climatic influences, and also aim at protecting the rights and interests of people living here. Some countries already have their own mountain laws (Kyrgyzstan). In Russia, the elements of mountain policy are based mainly on the example of some of its regions. At the federal level, the idea of a mountain law for the entire country has been raised, but has not yet found its embodiment.

The purpose of the article is to analyze modern initiatives in the field of legal support for the sustainable development of the mountain regions of Russia.

\section{Theoretical context}

\subsection{Natural differences and social inequality}

The basis of the initiatives undertaken in the field of legal support for the sustainable development of mountain areas is formed by studies and expert opinions that reveal the connection between the natural features of the mountains and the socio-economic problems of the mountain population, who find themselves in unequal conditions compared to the plains. Such problems include: remoteness and inaccessibility of mountainous areas, underdeveloped infrastructure, low competitiveness of products produced in the mountains due to higher costs, high unemployment, limited access to regional markets, migration of the population to the plains, delayed modernization, etc. [2-4]. At the same time, the aggregate value of mountain areas for the plains is high in terms of the preservation of natural landscapes and biodiversity, suppliers of fresh water, genetic resources, cultural diversity, etc. [5-6].

\subsection{Theoretical approaches to reflecting the specifics of mountain regions}

To reflect the specificity of the mountainous regions, various models have been developed. The earliest models include the accessibility model, which reveals the role of impassability, the costs invested to overcome the path, the limitations of a particular high-mountain region during different seasons. As a result, various functional mountain settlement systems are formed, oriented towards isolated existence or, to one degree or another, open to foreign markets. Different types of villages have their own balance of resource use: from subsistence farming to market-oriented [7]. The processes that shape the boundaries and structure of mountain ranges can be both natural and socio-cultural. For example, the commonality of the Alpine region, enshrined in the Alpine Convention, is associated with the mountain ecosystems of the Alps, the need to protect them and optimize the use of natural resources and conditions. The diversity of mountain regions and their landscapes leads to the development of different models and approaches. Models and concepts are being developed that reflect the nature of mountain institutions [8-9]. Globalization has revealed a number of problems in the development of mountain regions, the solution of which requires the development of models of crossborder development of mountain regions. A universal approach, which is becoming the most popular in the analysis of the problems of sustainable development of mountain areas, is the consideration of mountains as socio-ecological systems [10]. In Russia, the study of mountainous areas has considerable experience $[5,11$ 12]. In the early stages, the component analysis of the mountain environment prevailed. The development of an integrated vision has led to the development of problemoriented and socially-oriented approaches [13-15]. The substantiation of legal mechanisms for ensuring sustainable development of mountains is based on an integrated view of mountain areas as natural-economic and socio-ecological systems.

\section{Materials and methods}

The materials for the research were the main documents that touched upon the mountain policy abroad and in Russia. At the international level, these include: mountain laws of Georgia, Kyrgyzstan, France, etc., as well as Model Law "On the Protection and Development of Mountain Territories" (2020). At the federal level: The Federal Law "On Strategic Planning in the Russian Federation" (2014), the Spatial Development Strategy of the Russian Federation until 2025 (2019), the Fundamentals of State Policy for Regional Development of the Russian Federation for the period up to 2025 (2017), Implementation Plan for the Spatial Development Strategy of the Russian Federation for the period up to 2025 (2019) etc. Regional: Law of the Republic of Dagestan "On the mountainous territories of the Republic of Dagestan" (2010), Law of the Republic of North Ossetia-Alania (2019).

The analysis of legislative acts and other official documents was based on the selection of such key terms that characterize legal relations in mountainous territories, such as the concept of a mountainous territory, the boundaries of mountains. At the same time, the emphasis was on identifying the difference in wording in documents from different regions and countries.

In addition, an expert survey was conducted among the governments of the regions of the North Caucasus on the need to improve the legal framework, in particular, the need to give a special status to mountain municipalities (2019 survey).

A special block of methods accompanied the study of the effectiveness of mountain programs that have been adopted and are in the process of being implemented. Detailed field studies in Dagestan were devoted to the analysis of the results of the state program "Socio- 
economic development of mountainous territories of Dagestan", in particular, the effectiveness of financial instruments used since 2019 under this program. Field trips to the mountainous regions of Dagestan were accompanied by interviews with regional leaders and entrepreneurs who received financial subsidies from the state within the framework of the program.

Table 1. The level of awareness of the mountain specifics and practical steps in lawmaking at the level of the country and some (most active in mountain issues) regions

\begin{tabular}{|c|c|}
\hline $\begin{array}{r}\text { Co } \\
\text { re }\end{array}$ & specifics of mountain policy \\
\hline Russia & $\begin{array}{l}\text { The Implementation Plan for the Spatial } \\
\text { Development Strategy of the Russian } \\
\text { Federation for the period up to } 2025 \\
\text { (2019) includes clause } 60 \text { «On the criteria } \\
\text { for classifying municipalities of the } \\
\text { Russian Federation as mountainous } \\
\text { areas...» }\end{array}$ \\
\hline Dagestan & $\begin{array}{l}\text { The Mountainous Territories Law has } \\
\text { been adopted; the Action Program for the } \\
\text { Development of Mountainous Territories } \\
\text { has been implemented }\end{array}$ \\
\hline $\begin{array}{r}\text { North } \\
\mathrm{Al}\end{array}$ & $\begin{array}{l}\text { The first regional law on mountainous } \\
\text { territories in Russia (1998) was adopted, a } \\
\text { new version of it was adopted in } 2019\end{array}$ \\
\hline $\begin{array}{l}\text { The F } \\
\text { of In }\end{array}$ & $\begin{array}{l}\text { The law on mountain territories was } \\
\text { adopted in 2016, an initiative is being put } \\
\text { forward to develop a draft law and } \\
\text { program "On mountain territories of the } \\
\text { North Caucasus Federal District" }\end{array}$ \\
\hline $\begin{array}{l}\text { Chec } \\
\text { Repu }\end{array}$ & $\begin{array}{l}\text { The government decisions were adopted } \\
\text { on the development of two mountain } \\
\text { regions }\end{array}$ \\
\hline $\begin{array}{l}\text { Kabardino- } \\
\text { Balkar } \\
\text { Republic }\end{array}$ & $\begin{array}{l}\text { No special law was adopted, the } \\
\text { government emphasizes the uncertainty of } \\
\text { the boundaries of the mountainous } \\
\text { territory }\end{array}$ \\
\hline $\begin{array}{l}\text { Stavropol } \\
\text { region }\end{array}$ & $\begin{array}{l}\text { There are no proposals on the criteria for } \\
\text { classifying municipalities as mountainous } \\
\text { areas. }\end{array}$ \\
\hline $\begin{array}{l}\text { Karachay- } \\
\text { Cherkessia }\end{array}$ & $\begin{array}{l}\text { The government considers it inexpedient } \\
\text { to give a special status to mountain } \\
\text { municipalities }\end{array}$ \\
\hline $\begin{array}{c}\text { Altai } \\
\text { Republic }\end{array}$ & $\begin{array}{l}\text { A special law was not adopted, but the } \\
\text { republic came out with an initiative to } \\
\text { prepare a federal law on mountain } \\
\text { territories }(2005)\end{array}$ \\
\hline
\end{tabular}

\section{पाResults and Discussion}

\section{Q.1 Document analysis results}

As the analysis of documents accompanying the institutionalization of mountainous regions has shown, decisions are distinguished that are recommendatory in nature (declarations, conventions, charters, etc.), and mandatory documents (laws, regulations) [16].

A special place in the history of legal regulation of the development of mountainous territories is occupied by the legislative work of such countries as Switzerland, France, Bulgaria, Georgia, Kyrgyzstan, Tajikistan, etc.
In these states, mountainous areas have a special status, laws are in force aimed at improving the living conditions of highlanders. At the same time, the fundamental concept for the institutionalization of the specificity of the respective regions is the definition of a mountainous territory.

Based on published sources, the delineation of the mountainous area differs from country to country (Table 2) [17-21]. In France, a mountainous zone is considered to be the territory of communes where at least $80 \%$ of the area is located above $600 \mathrm{~m}$ above sea level or in which the difference in elevation between the lower and upper boundaries of cultivated land is at least $400 \mathrm{~m}$. The European Agricultural Fund for Rural Development refers to mountain areas, eligible for government payments, territories where the possibilities of using the land are very limited, and the cost of its processing is much higher than usual (due to the peculiarities of the climate and relief, or a combination of these two factors). Regions located north of the $62 \mathrm{nd}$ parallel, and some adjacent territories, are considered mountainous areas.

Table 2. Delineation criterion in the one-criterion method Country Minimum elevation [17]

\begin{tabular}{|c|c|c|}
\hline Country & $\begin{array}{l}\text { Minimum } \\
\text { Elevation (m) }\end{array}$ & Additional criteria \\
\hline Austria & 700 & $\begin{array}{l}\text { also above } 500 \mathrm{~m} \text { if slope } \\
>20 \%\end{array}$ \\
\hline Bulgaria & 600 & $\begin{array}{l}\text { also altitudinal difference } / \mathrm{km}^{2} \\
>200 \mathrm{~m} \text { or slope }>12^{\circ}\end{array}$ \\
\hline Cyprus & 800 & $\begin{array}{l}\text { also above } 500 \mathrm{~m} \text { if average } \\
\text { slope }>15 \%\end{array}$ \\
\hline France & $\begin{array}{l}700 \text { (generally) } \\
600 \text { (Vosges) } \\
800 \\
\text { (Mediterranean) } \\
\end{array}$ & $\begin{array}{l}\text { In the case of Vosges: slope } \\
>20 \% \text { over }>80 \% \text { of area }\end{array}$ \\
\hline Germany & 700 & climate difficulties \\
\hline Greece & 800 & $\begin{array}{l}\text { also } 600 \mathrm{~m} \text { if slope }>16 \% \text {, } \\
\text { below } 600 \mathrm{~m} \text { if slope }>20 \%\end{array}$ \\
\hline Hungary & 600 & $\begin{array}{l}\text { also above } 400 \mathrm{~m} \text { if average } \\
\text { slope }>10 \% \text { or average slope } \\
>20 \%\end{array}$ \\
\hline Italy & 600 & altitudinal difference $>600 \mathrm{~m}$ \\
\hline Poland & 350 & $\begin{array}{l}\text { can be lower if slopes }>12^{\circ} \\
\text { for }>50 \% \text { of agricultural land } \\
\text { in a municipality }\end{array}$ \\
\hline Portugal & $\begin{array}{l}700 \text { (north of } \\
\text { the Tejo river) } \\
800 \text { (south of } \\
\text { the Tejo river) }\end{array}$ & slope $>25 \%$ \\
\hline Romania & 600 & also on slopes $>20^{\circ}$ \\
\hline Slovakia & 600 & $\begin{array}{l}\text { above } 500 \mathrm{~m} \text { on slopes }>7^{\circ} \text { or } \\
\text { average slope }>12^{\circ}\end{array}$ \\
\hline Slovenia & 700 & $\begin{array}{l}\text { also above } 500 \mathrm{~m} \text { if more than } \\
\text { half the farmland is on slopes } \\
\text { of }>15 \% \text { or slope }>20 \%\end{array}$ \\
\hline Spain & 1000 & $\begin{array}{l}\text { slope }>20 \% \text {, elevation gain } \\
400 \mathrm{~m}\end{array}$ \\
\hline
\end{tabular}

In Germany and Austria, mountains are recognized as an area located above $700 \mathrm{~m}$ above sea level. At the same time, in Austria, territories at an altitude of $500 \mathrm{~m}$ 
are also taken into account if the slopes occupy more than $20 \%$ of their area. In Poland, the mountains begin as early as $350 \mathrm{~m}$ and can be even lower if slopes with a steepness of more than 12 degrees account for at least $50 \%$ of the agricultural land in the municipality. About two-thirds of Switzerland is defined as "mountains" under the federal investment law.

As shown by the synthesis of documents and survey results, the level of awareness of mountain specifics and practical steps in lawmaking in the field of mountains are very different (Table 1). Mountain regions twice came up with proposals to the federal level with the need to develop laws on the mountainous territories of Russia. The first initiative belongs to the Altai Republic in 2005. In fact, the entire region is mountainous. Therefore, the adoption of a special mountain law within the republic did not take place. The situation is different in the regions of the North Caucasus. Here the leadership belongs to North Ossetia-Alania and Dagestan, which adopted laws on mountain areas, as well as the Program for the implementation of the legislative framework. The successful experience of Dagestan made it possible to return again to the initiative to develop a federal law on the mountainous territories of Russia. But this time, too, the initiative was deemed inappropriate. It is noteworthy that not all mountain republics share the opinion about the advisability of giving mountain municipalities a special status (for example, Karachay-Cherkessia). The understanding of what is so important in a territory that is mountainous, where the boundaries between mountains and not mountains pass, differs enough from region to region.

In Russia, at the regional level, several definitions of the concept of "mountainous territory" are fixed at once. For example, according to the Law of the Republic of Dagestan (2010), such a territory is considered to be an area located above $1000 \mathrm{~m}$ above sea level, as well as an area with rugged relief and an elevation of $500 \mathrm{~m}$ in a radius of $25 \mathrm{~km}$. According to the Law of the Republic of North Ossetia-Alania (2019), a mountainous territory is understood as a terrain with rugged relief and an absolute relief height of more than $800 \mathrm{~m}$.

Regional proposals to develop a federal mountain law were rejected $(2005,2016)$. As part of the implementation of the State Strategy for Spatial Development of the Russian Federation for the period up to 2025, consultations began on the preparation of criteria for the selection of mountain municipalities.

A study of the situation in the regions of the Russian Federation showed that purely formal criteria, such as absolute height above sea level, are not enough to classify a municipality as a mountainous area. According to the results of geoinformation calculations, mountains occupy about $8 \%$ of the area of the Russian Federation, if we assume that they start from $1000 \mathrm{~m}$, and $40 \%$ - if we take into account the territories located above $300 \mathrm{~m}$. may be below $300 \mathrm{~m}$.

The difference between the maximum heights of the location of settlements in different mountain regions can be significant. For example, in the Western Caucasus, the upper mark for settlements is $1600 \mathrm{~m}$ (Dombai), and in the East - $2650 \mathrm{~m}$ (the village of Kurush). In the Urals, in the mountains of Siberia and in the Far East, the overwhelming number of settlements are located below $1000 \mathrm{~m}$, but rare places of settlement in the mountains of Southern Siberia, for example, in Altai, are located at a level of $1500 \mathrm{~m}$ and above. The lands above them are uninhabited, but the local population uses them for pasture cattle breeding and includes them in tourist routes.

Counting the population in mountainous areas revealed a significant difference between the scale of formal (according to registration) and actual residence. So, in Dagestan, most of the inhabitants officially assigned to mountain settlements live on the plains (in kutans), and in the mountains they visit only from time to time.

To develop criteria for classifying a municipality as a mountainous territory, it is first necessary to single out mountain zones characterized by a special complex of living conditions and environmental management, analyzing the nature of the location of settlements there, as well as the bulk of land used by the population (regardless of where it lives). The list of mountain municipalities should be determined by the constituent entities of the Russian Federation, based on the historically established settlement system and a detailed analysis of natural and socio-economic conditions with the involvement of scientists, experts and representatives of local municipalities. Only then can both natural and historical and economic aspects be fully taken into account.

Table 3. Distribution of the area of Russia and the regions of the North Caucasus by heights (\%)

\begin{tabular}{|l|c|c|c|c|}
\hline & $>\mathbf{3 0 0}$ м & $>\mathbf{5 0 0}$ м & $>\mathbf{8 0 0}$ м & $>\mathbf{1 0 0 0}$ м \\
\hline Russia & 40 & 25 & 13 & 8 \\
\hline $\begin{array}{l}\text { Karachay- } \\
\text { Cherkessia }\end{array}$ & 100 & 97,8 & 85,2 & 77 \\
\hline $\begin{array}{l}\text { North } \\
\text { Ossetia } \\
\text { Alania }\end{array}$ & 90,8 & 77 & 55,6 & 48,1 \\
\hline Ingushetia & 90,8 & 66,7 & 32,8 & 25,7 \\
\hline $\begin{array}{l}\text { Kabardino- } \\
\text { Balkaria }\end{array}$ & 80,9 & 66,7 & 53,9 & 47,3 \\
\hline Dagestan & 50,9 & 46,7 & 42,2 & 39,7 \\
\hline Adygea & 44,8 & 32,2 & 22,1 & 17,3 \\
\hline $\begin{array}{l}\text { Chechen } \\
\text { Republic }\end{array}$ & 43,5 & 35,9 & 27,2 & 24 \\
\hline $\begin{array}{l}\text { Stavropol } \\
\text { region }\end{array}$ & 22,2 & 5,7 & 1,2 & 0,7 \\
\hline $\begin{array}{l}\text { Krasnodar } \\
\text { region }\end{array}$ & 21,4 & 13 & 6,1 & 4,3 \\
\hline
\end{tabular}

The need for different approaches to the definition of mountain altitude levels and, accordingly, the list of measures to support mountain municipalities is indirectly indicated by the data on the distribution of mountain territories in regions by height (Table 3). The most "mountainous" in the North Caucasus should be considered Karachay-Cherkessia. Here, the entire territory is located at an altitude of more than 300 
meters, and more than three quarters - above 1000 meters above sea level. In 2020, when the regions were polled on the advisability of giving the status of mountain to municipalities, the leadership of KarachayCherkessia recognized this practice as not advisable in the republic. However, it should be noted that the overwhelming majority of the population of this republic lives within up to $700 \mathrm{~m}$ above sea level [22]. Significantly large differences and "weight" of the mountain population are observed in Dagestan.

\subsection{Dagestan's experience in the legal sustainable development of mountainous areas}

The mountainous territories of Dagestan occupy more than half of the republic's area. However, it is in the mountains that more than three quarters of all settlements are located (about 1200). At the same time, 452 settlements are classified as hard-to-reach according to the Law of the Republic of Dagestan "On the list of hard-to-reach and remote areas in the Republic of Dagestan" (2006). The inaccessibility and other unequal living conditions with the plains lead to unemployment and push the highlanders to resettlement to the plains. To implement measures for the development of mountainous areas, the state program "Social and economic development of mountainous areas of Dagestan" was developed and implemented. Its main goals are devoted to improving the socio-economic situation of the mountainous territories of the republic, increasing the well-being and quality of life of the mountain population and ensuring sustainable economic growth of mountainous territories [23].

The objectives of the program have a clear economic focus, implying, through economic incentives and preferences, to ensure the achievement of goals. These include, in particular, the provision of state support in the implementation of small investment projects, the stimulation of entrepreneurship in the mountains, etc. Therefore, the target indicators of the program characterize mainly the economic block: the volume of agricultural production, the volume of processed agricultural and industrial products, the volume of investments in fixed capital, the number of new jobs, the average monthly salary of the population of mountainous areas, etc. It is expected that the implementation of the program will increase the economic potential of mountainous areas, increase the investment attractiveness of municipalities in the mountainous zone, create conditions for reducing the outflow of population from the mountains, etc.

Subsidies are provided for the construction of small greenhouses, product storage centers, for reimbursement of part of the cost of purchasing equipment for the production of food products, purchasing small equipment, etc. In total, 87 applications out of 18 were received in 2021 (Sun its 30) mountainous regions. This is much more than in 2020 (19 applications). Nevertheless, interest in the program among mountain residents is relatively low. This is due to many factors. The main factor of passivity of participation in the program can be considered still weak consulting and explanatory work. Along with poor awareness among the population, there remains distrust of the authorities' initiatives. The population is afraid of inspections and control by law enforcement officers, not trusting them. In the context of the complexity of reporting, many are afraid to get into credit and financial dependence.

Expeditionary research also showed that many promising activities were not covered by support. These include, in particular, the production of feed for livestock, the purchase of pedigree young stock, the cost of equipping small farms, providing autonomous power supply, etc. reporting form, etc.

The most important obstacle to participation in the program is the imperfection of land relations, first of all, the presence of informal land relations, the use of land according to traditional laws, the lack of motivation to register plots for use, conflicts between land users, etc.

\section{Conclusion}

The mountainous territories of Russia are still poorly reflected in special laws aimed at equalizing natural differences. Unlike the Arctic regions, which have many years of experience in implementing laws and regulations that provide compensation for difficult living and working conditions in the North, the mountainous regions of Russia are just beginning to stand out in the legal field. A big step has been taken at the regional level on the example of the implementation of mountain laws in Dagestan and North Ossetia-Alania. The institutionalization of these mountainous regions comes up against the need to legalize traditional practices, mountain adats. Nevertheless, some of the traditional rules remain informal, playing an important role in the regulation of mountain environmental management at the local level. The program for the development of the mountainous territories of Dagestan, initiated on the basis of the development of the implementation of the law on mountainous territories, became a certain "litmus" test that revealed the problems of modernization and ensuring sustainable development in the mountains.

\section{References}

1. Yu.P. Badenkov, J. Sustainable Development of Mountain Territories. 9(2), 111-119 (2017).

2. B. Messerli, J.D. Ives, Mountains of the World: A Global Priority, (Parthenon Publishing, New York and Carnforth, 1997).

3. V.M. Kotlyakov, Yu.P. Badenkov, Foreword, Mountains of the World. Global priority, (Moscow, Noosphere, 1999).

4. M. Price, Mountains: A Very Short Introduction, (OUP Oxford, 2015).

5. V.M. Kotlyakov, Yu.P. Badenkov, K.V. Chistyakov, Mountain research. Mountain regions of northern Eurasia. Development in the context of global changes, Questions of geography, Issue 137, 
(Russian Geographical Society, Moscow, Publishing house "Kodeks", 2014).

6. B. Debarbieux, M.F. Price, Mountain Research and Development. 32(1), 7-11 (2012).

7. N. Allan, Mountain Research and Development. 6(3), 185-194 (1986).

8. A. Castelein, T.T.V. Dinh, M.A. Mekouar, A.Villeneuve, Mountains and the Law. Emerging Trends. FAO Legislative Study - 75, Rev. 1, (Rome: Food and Agriculture Organization of the United Nations 2006).

9. C. Adler, J. Balsiger, A. Grêt-Regamey, A. Heinimann, C. Huggel, R. Weingartner, I. Alcántara-Ayala, A. Gebrekirstos, R. Grau, E. Jimenez Zamora, Mountain Research and Development. 40(1), 1-6 (2020).

10. J.A. Klein, C.M. Tucker, A.W. Nolin, K.A. Hopping, R.S. Reid, C. Steger, et al. Earth's Future, 7 (2019).

11. Yu.P. Badenkov, A.N. Dunets, Sh.S. Muduev, Kh.M. Mukhabbatov, J. Sustainable Development of Mountain Territories. 8(4), 323-337 (2016).

12. Sh. Muduev, H. Mukhabbatov, International scientific and analytical journal of the Interparliamentary Assembly of the stateparticipants of the CIS. 3(14), 32-38 (2019).

13. A. Gunya, Institutional restructuring of geographic space: the impact of land privatization on the mountainous landscapes of the North Caucasus, (Palmarium Academic Publishing, Saarbrücken, 2013).

14. A.N. Gunya, J. Sustainable Development of Mountain Territories. 3(25), 15-22 (2015)

15. A. Gunya, Revue de géographie alpine, 105(1), (2017).

16. E.A. Galinovskaya, Questions of state and municipal administration. 1, 166-196 (2020).

17. M. Pantić, Journal of the Geographical Institute Jovan Cvijic SASA. 65(1), 43-58 (2015).

18. Mountain Areas in Europe: Analysis of mountain areas in EU member states, acceding and other European countries. Final report for the European Commission. Nordic centre for spatial development (2004). Available https://ec.europa.eu/regional policy/sources/docgen er/studies/pdf/montagne/mount1.pdf. [Accessed 28 July 2021].

19. Report of the Committee of the Regions on 'Community action for mountain areas'. Official Journal of the European Union. 128(05), (2003).

20. White Book 2000 on Mountain Forests in Europe. European Observatory of Mountain Forests, (European Union DG Agriculture and EOMF, Saint Jean d'Arvey 2000).

21. T. Treves, L. Pineschi, A. Fodella, Sustainable Development of Mountain Areas - Legal
Perspectives beyond Rio and Johannesburg, (University of Milan, Milano 2004).

22. A.N. Gunya, Dynamics of the development of a mountainous region: structural and institutional factors (on the example of the dynamics of settlement and land use in Kabardino-Balkaria and Karachay-Cherkessia), (Nalchik, KBSC RAN, 2008).

23. Decree of the Government of the Republic of Dagestan dated February 18, 2020 No. 21 On approval of the state program of the Republic of Dagestan "Social and economic development of mountainous territories of the Republic of Dagestan" and amending the List of state programs. http://www.e-dag.ru/2013-05-27-06-5430/postanovleniya-pravitelstva-rd/postanovleniepravitelstva-rd-ot-18-fevralya-2020-g-21-obutverzhdenii-gosudarstvennoj-programmyrespubliki-dagestan-sotsialno-ekonomicheskoerazvitie-gornykh-territorij-respubliki-dagestan-ivnesenii-izmeneniya-v-perechen-gosudarstvennykhprogramm.html. 